\title{
Developing Children's Social Emotional: Women's Leadership Review
}

\author{
Moh. Anwar ${ }^{1 凶}$ \\ Manajemen Pendidikan Islam, Universitas Islam Negeri Kiai Haji Achmad Siddiq Jember, \\ Indonesia ${ }^{(1)}$ \\ DOI: 10.31004/obsesi.v6i3.1836
}

\begin{abstract}
This study aims to analyze and understand women's leadership in building children's emotional-social intelligence in PAUD Aisyiyah Gilimanuk Jembrana Bali. The qualitative case study method is used in this investigation. The information was gathered through a combination of observation, interviews, and documentation. The data analysis was carried out circularly, beginning with data collection and progressing through data reduction, presentation, and conclusion. As a result of the findings; PAUD Aisyiyah is a female leader who is highly dedicated to creating a polite culture program to build children's emotionalsocial intelligence. Efforts to construct emotional-social intelligence are carried out properly through the following stages; reliable leadership for early childhood, educator for teachers and students, managerial and administrator, supervisor, innovator, and motivator. This research has implications for the importance of female leaders in building an excellent organizational culture, especially in creating emotional-social intelligence for children at school, through the involvement of all components.
\end{abstract}

Keywords: female leadership; intelligence; social emotional

\begin{abstract}
Abstrak
Penelitian ini bertujuan untuk menganalisis dan memahami tentang kepemimpinan perempuan dalam membangun kecerdasan sosial emosional anak di PAUD Aisyiyah Gilimanuk Jembrana Bali. Penelitian ini menggunakan pendekatan kualitatif jenis studi kasus. Pengumpulan datanya dilakukan melalui observasi, wawancara dan dokumentasi. Analisis datanya dilakukan secara sirkuler, yang dimulai dari pengumpulan data, reduksi data, penyajian data dan diakhiri dengan penarikan kesimpulan. Hasil penelitian menunjukkan bahwa; kepemimpinan di PAUD Aisyiyah merupakan pemimpin perempuan yang berdedikasi tinggi dalam menciptakan program budaya santun guna membangun kecerdasan sosial emosional anak. Ikhtiar dalam membangun kecerdasan sosial emosional dilaksanakan dengan baik melalui tahapan berikut; leadership handal untuk anak usia dini, educator bagi guru dan anak didik, manajerial dan administrator, supervisor, inovator dan motivator. Penelitian ini memberikan implikasi tentang pentingnya pemimpin perempuan dalam membangun budaya organisasi yang baik, khususnya dalam menciptakan kecerdasan sosial emosial anak di sekolah, melalui pelibatan semua komponen yang ada di dalamnya.
\end{abstract}

Kata Kunci: kecerdasan; kepemimpinan perempuan; sosial emosional

Copyright (c) 2021 Moh. Anwar

$\triangle$ Corresponding author :

Email Address : mohanwar0268@gmail.com \{Jember, Indonesia)

Received 1 July 2021, Accepted 26 October 2021, Published 26 Desember 2021

Jurnal Obsesi : Jurnal Pendidikan Anak Usia Dini, 6(3), 2022 | 2095 


\section{INTRODUCTION}

To create a superior generation and compete in the digital era, the implementation of education must provide the amplest opportunity for students to grow and develop according to their potential, talents, interests, and abilities (Baharun, 2016). Organizing education that frees children from the smell of violence without giving up the provision of education that treats children in a friendly manner (Salgado et al., 2020). At the same time, organizing education that humanizes children (humanization) to realize education to fulfill children's rights (Maysaroh, 2019; Br \& Asiya, 2021).

Early childhood education is an effort to encourage guidance, care, and stimulation, leading to children's abilities and skills (Fardiah et al., 2019; Zamroni et al., 2021). Education for early childhood is carried out through the method of playing while learning through games so that children will get enjoyable learning, especially during the golden age, which is around the age of 0-6 years (Islaeli et al., 2020; Iltiqoiyah, 2020; (Umiarso et al., 2022).

Playing while learning is the right way to stimulate learning in early childhood at school (Fachri et al., 2020). Activities that get natural and fun results, namely from games, developmental aspects, can be entirely achieved through games (Aulina, 2018; Minasari et al., 2021). Through games, a child can also encounter new things and can reinforce experiences that children have known before using expression and exploration carried out by children (Yarmi \& Wardhani, 2020; Fika et al., 2019; Finori, 2019). The importance of playing for children encourages child development to grow naturally, starting from elements of the development of religious and moral values, social, emotional, language, cognitive, physical motor, and art (Putri \& Widiastuti, 2019; Zulkarnain et al., 2020). One of the essential aspects to be developed as a provision for living in a social environment is the socio-emotional aspect (Sinaga \& Doang, 2020).

Children who have adequate social-emotional development are believed to be able to dynamize the learning environment and build a conducive climate, thereby creating enthusiasm and motivation to learn (Fajri et al., 2021; Mahmud et al., 2021). For this reason, social-emotional development is an important thing that every child must own to establish good relationships with teachers and fellow children in the class so that the learning objectives in the classroom can be achieved (Oktaria \& Anggraeni, 2016; Baharun \& Astriani, 2019).

Social-emotional development, namely the child's daily developmental behavior, can be related to his habits, consisting of a unitary trait, since in the womb (Fardiah et al., 2019). Research on studying children's behavior has been carried out since 1960. Characteristics of children's behavior have been shown since the child was born. Although the range of socioemotional development continues throughout life, many experts agree that it is essential to develop it for children from infancy to good age (Aisyah et al., 2018; Rahmatika et al., 2019). If this is not done, then the child's development will slow down; the child is less able to make decisions, cannot adapt to his environment, and cannot control his emotions.

Social emotional development is characterized by the ability to socialize through the learning process to become social beings. As a process, socialization is a process in which children develop their sensitivity to social stimuli, particularly the pressures and demands of life (groups), and learn to get along with others by acting and behaving in ways that are similar to those of other people in their social environment (rent). Similar to the development of further intelligence, social intelligence also requires the right stimulus to be appropriately integrated as it should.

Many studies on early childhood social intelligence include Nurjannah, (2017) says that early childhood social-emotional development is how children interact with others by established social rules. Children who can identify and express their emotions can better maintain control over their feelings as they grow older. Children's social-emotional development occurs gradually and is accompanied by strengthening and modeling.

Furthermore, Nurhasanudin \& Santika, (2021) say; "the ability of children's emotional intelligence, namely the knowledge, skill, and strength, to do an act that they are born with 
through training". Then Susanto, (2011) argue that; "aspects of social development include tolerance, caring, mutual respect, mutual respect, cooperation, empathy, etc". Meanwhile, what is meant by the emotional element is fear, joy, happiness, sadness, etc.

Not all children are successful in completing the task of social-emotional development at an early age, and as a result, a variety of difficulties can arise. When it comes to children's social and emotional development, it is appropriate for educators to see it as a provision in guiding children to develop their social and emotional abilities properly, according to the National Council of Teachers of Social and Emotional Development.

Based on the results of observations made at PAUD Aisyiyah, some children experience obstacles in their learning that come from within because their social, emotional skills are still lacking. This lack of dynamic, social skills can be seen from a lack of self-confidence, lack of obedience to rules, lack of patience when waiting for their turn or when listening to other people speak, lack of independence, lack of a caring attitude towards others, or a sense of tolerance, lack of responsibility for the games that are done, so that cause other difficulties in the child to follow the rules given by the teacher.

In overcoming this, a breakthrough is needed in building children's emotional-social intelligence through the involvement of reliable leaders and able to overcome existing problems. Dedicated leadership is something that every organizational leader should have in overcoming problems (Fauzi \& Muali, 2018). The expertise of leaders in directing their members will create the effectiveness of their leadership (Sutanto, 2000; Hefniy et al., 2020). Morale, comfort, security, quality of work, and an organization's level of achievement are influenced by a leader. Therefore, it takes a leader who is able to achieve organizational goals in PAUD Aisyiyah, in order to be able to build children's emotional social intelligence.

PAUD Aisyiyah chose the involvement of a woman in fostering the organization. This is because the participation of women, especially in early childhood education, is considered to be able to protect, nurture, guide, and establish close relationships in controlling children's social emotions (Wibowo, 2021). The motherly nature and tenderness possessed by a woman can give a child a sense of comfort.

This departs from previous research, including Halilah (2012) which stated that "women's leadership in educational organizations positively influences students because women's gentle attitudes can understand the character of their students, especially in early childhood". A woman as a school principal can realize an outstanding school because work related to education and attention and affection for children and adolescents is a tendency of women in general (Sudrajat et al., 2020).

Nurvita et al., (2020) said that women's leadership could also create effective leadership because women have advantages in playing and creating organizational effectiveness. Women leaders are expected to create good, comfortable parenting patterns, especially for early childhood, in developing future generations of quality, faith, excelling in personality (Yulianto, 2016).

Sholehah et al., (2016) said that women's laeadership has several advantages, including; First, women are synonymous with gentleness, calmness, and humility. Second, Have analytical and careful nature. By having these characteristics, a leader will be more cautious in making decisions. Third, better understand and understand what his subordinates want. With some of the features of a woman, leading will provide comfort to her subordinates. Education for early childhood is expected to stimulate its development to support its future (Wahid et al., 2018). Appropriate stimulation is expected to be able to build children's emotional, social intelligence in interacting with their environment.

The presentations from several researchers explained the importance of women's leadership towards early childhood in stimulating and building children's emotional-social intelligence in creating a sense of responsibility for themselves and others.

Departing from the above, the researchers are interested in reviewing women's leadership in building children's emotional, social intelligence. The focus of this study aims to 
analyze women's leadership in building children's emotional-social intelligence with the right stimulus in PAUD Aisyiyah Gilimanuk Jembrana Bali.

\section{METHODOLOGY}

There is a qualitative research type of case study in this investigation. The emphasis is on a thorough description of the role, supporting factors, and efforts put forth by the research subjects in the study. Description: The purpose of this descriptive research is to develop a systematic, factual, and accurate description of the facts, properties, and relationships between the investigated phenomena, as well as a picture or painting of those facts, properties, and relationships between the studied phenomena, in the form of language and text, in a specific natural context, using various natural methods.

It was conducted in a Bali early childhood education institution, specifically at PAUD Aisyiyah, and the findings were published in this journal. This study aims explicitly to describe women's leadership in building emotional, social intelligence in children.

Research subjects and informants in the study include; principals, teachers, parents, and students. Observations were carried out by directly observing field conditions and conducting semi-structured interview sessions with several randomly assigned teachers to obtain authentic information. The researcher then triangulated the data to analyze the self-evaluation data by policymakers, teachers as policy implementers, and natural conditions in the field.

The data analysis technique in this study uses the concept of Milles \& Huberman (2014), namely data collection, data reduction, data presentation, and ends with concluding, which can be described as in picture 1.

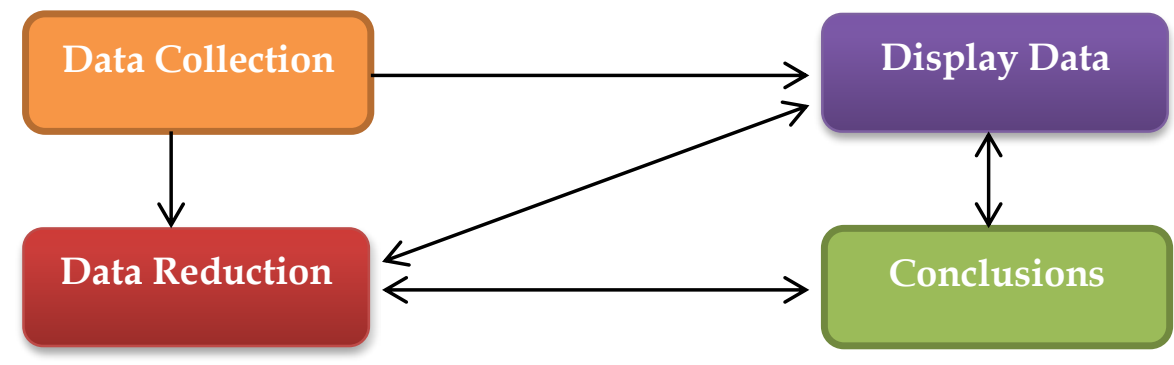

Picture 1. Data Analysis Technique

\section{RESULTS AND DISCUSSION}

The results of the study indicate that women's leadership in building emotional-social intelligence at the PAUD Aisyiyah is as follows;

\section{Reliable Leadership for Early Childhood}

The ability of women to lead a community, especially those related to early childhood, is undoubted; women who have a gentle attitude full of affection have the advantage of providing comfort to early childhood compared to male leaders. Women as school leaders can also formulate the school's vision, mission, goals, and objectives and disseminate them to the school community.

IF1 as the principal of PAUD Aisyiyah Gilimanuk Jembrana Bali, said we are trying our best for the institution's progress by developing a vision and mission to achieve the goals we expect. It's not just a vision and mission that is displayed. Still, we try to apply it to our institution with the support of parents and the community to achieve the overall development goals of students. IF2, one of the teachers also said, the fighting spirit of the PAUD Aisyiyah principal in advancing the institution made us also moved to do positive things, especially in producing a generation that develops in every aspect of intelligence, so that students can improve their achievements better. 
Female principals can maintain and foster a positive school climate well, can lead, and are willing to act boldly and thoughtfully. They can arrange teaching supervision programs and help teachers improve their teaching performance, monitor student achievement to improve academic achievement effectively. IF4, one of the teachers, also thought that our school principal could create a good socialization climate between leaders and subordinates, between colleagues, students, and parents. A well-created socialization climate awakens us to be more passionate about innovating to create increased student achievement.

IF3 as the guardian of students, also said that PAUD Aisyiyah provided opportunities for parents to partner well by always involving us as guardians of students in school activities such as associations, parenting, school greening, and school routine events. This forms good socialization between the parents of students and the school to find consensus in growing and building students' talents on target.

The principal can involve parents in school activities through good socialization relationships by responding to the expectations of parents or the community regarding building the intelligence and talents of children. From the results of this study, it can be understood that women's leadership has a great attitude in guiding and directing teachers to develop children's social emotions. This is inseparable from the transformative and feminist perspective of a leader who seeks to optimize all the potential teachers and students possess.

\section{Educator for Teachers and Students}

The principal's leadership as an educator in improving the competence of teachers, students, and guardians of students, the principal must be able to create a conducive school climate from all aspects. IF2, as the homeroom teacher conveyed, in building children's emotional-social intelligence, which is continually promoted by the polite culture program at PAUD Aisyiyah, the principal has always been a good educator for us, teachers, in carrying out their duties by setting an example of a good attitude, good advice, giving encouragement to all teachers to apply innovative and exciting learning models.

IF5 as a teacher said that the education applied by school principals to teachers, especially in building children's social intelligence, was carried out by various methods and tricks ranging from refraction such as; greet, ask, say politely, be patient, confident. In addition, he also suggested that teachers provide interaction stimulation to children so that children can interact with teachers and friends well. Children can be responsible for their duties and independently carry out their activities through teacher supervision.

IF3 also emphasized that the educational support provided by the school principal was not only through words and actions but also in the form of offering supporting facilities and infrastructure to build six aspects of children's development, including emotional-social intelligence, such as the completeness of APE (Educational Props) in learning both internally and externally. Outside, provision of handwashing places, habituation of queuing culture, prayer rooms, libraries, etc.

As a good educator, the principal can create and build a more creative, innovative, and independent institution in publishing superior generations in the future.

\section{Managerial and Administrator}

The principal as the school manager is responsible for preparing school plans, designing and coordinating activities, monitoring and evaluating all activities, regulating the learning process, making decisions, holding meetings, managing administration, and managing administration, students, personnel, facilities, and infrastructure and finances.

IF5 conveyed that the principals of PAUD Aisyiyah were good managers in managing the school environment, which was organized in such a way that it could provide and meet school needs, such as managing activities that would be carried out by teachers in building children's intelligence by providing training and guidance for all teachers on duty. The administration is an activity in completing all school files, especially the ways that will be 
taken to achieve the goals of the organization itself through the administrative function. With proper administration, achieving organizational goals will be more focused and more accessible.

IF4 said that the principal of PAUD Aisyiyah is an administrative leader, all school apparatus related to administration must be completed before learning begins. The principal's executive order makes it easier for all employees or teachers to manage school administration from students, teachers, school officials, and others. IF2 also said that with complete management and administration, we as teachers could see students' level of achievement through recording daily, weekly, monthly, and semester assessments. So when we are going to fill out the evaluation in the report card, we as teachers already have an assessment file to copy on the report card and distribute it to the parents.

Good managers and administrators can accommodate all children's development through structured assessment records. When conducting an evaluation, both the head and teacher understand the level of achievement achieved by the child. They can find solutions for the level of accomplishment that has not been developed optimally.

\section{Supervisor, Innovator and Motivator}

The supervisor is authorized or has the authority to supervise, direct a technical or procedure systematically and control the implementation of other systems, namely by giving orders to subordinate staff under the direction of his superior position. The renewal or innovation in PAUD Aisyiyah can be interpreted as a process or result of developing knowledge, skills, and experience to create or improve the quality of a new system, which provides significant helpful value.

Giving encouragement or stimulation to someone to further improve the quality of life is called a motivator. In this case, the leadership of PAUD Aisyiyah always motivates teachers to show their best performance in educating children at school, which is carried out directly or indirectly through coaching, supervision, delegation activities at seminars, workshops, and educational activities and training.

IF2 said that the leadership carried out by the IF1 school principal was very instrumental in building students' intelligence, marked by the principal's activeness in supervising teachers who were tasked with stimulating the development of students, especially in the development of children's emotional, social intelligence. The school principal manages by controlling and directing how teachers work in the classroom and outside the school; the principal also assesses our performance as teachers and then evaluates the shortcomings that need to be addressed for the sustainability of the polite culture program in our institution.

IF4 also agrees with IF2 that the supervision carried out by the principal has produced results with the holding of learning system innovations in terms of building children's emotional, social intelligence by making good habits related to dynamic social such as the application of independence, discipline, interacting, sharing, saying politely, mutual help (care), cooperation, and so on. With the promotion of a polite culture program in habituation at PAUD Aisyiyah, it is providing an understanding to students about the importance of controlled social and emotional, so that it can motivate students in building social, emotional intelligence in everyday life in the school environment and at home.

IF3 also conveyed that with the polite culture innovation promoted in schools, the principal always motivates us, teachers or educators, to be even more active in proclaiming this culture. The motivation carried out by the principal is not only to the teachers and students but also to the guardians of the students, where the guardians of the students are in control of the habits or character of the students in behaving. Motivation is carried out to schools and teachers to parents about the importance of polite culture programs in developing children's emotional and social intelligence. This is expected to establish good cooperation between 
school members and parents and produce the expected output. These namely students can develop at the level of emotional, social intelligence.

The stimulation of emotional-social intelligence can be carried out in PAUD Aisyiyah through effective collaboration between teachers, parents, and students, thanks to women's leadership in the school. In this instance, the principal fulfills their leadership responsibilities. According to the National School Boards Association, the principal is a critical factor in motivating schools to achieve their vision, mission, goals, and objectives through programs implemented in a planned and gradual manner. As a result, leadership is defined as an activity that involves influencing others to achieve predetermined goals. School principals must control and mobilize school resources to plan and evaluate school programs, curriculum development, learning, workforce management, learning facilities and resources, finance, student services, school relations with the community, and creating a positive school climate, among other responsibilities.

Principals are responsible for guiding teachers, education staff, and students while keeping up with scientific and technological developments and setting a positive example for the rest of the school (Munawar, 2019). Rusmawati, (2013) explained that to create a conducive school climate, cooperation or harmonious relationships were needed between all school members and not only the principal's responsibility. The efforts that school principals can make to improve performance as educators, particularly in enhancing performance as educators, particularly in improving the performance of educational staff and student learning achievement, are as follows: involve teachers in further education by encouraging them to begin creatively and achieve success in the classroom (Baharun, 2017; Ilyasin \& Zamroni, 2017; Aryani et al., 2021).

A school principal's responsibilities include planning, coordinating activities, supervising activities, evaluating activities, holding meetings, and making decisions. They are also responsible for regulating the learning process, managing administration, overseeing the administration, students, personnel, facilities and infrastructure, and financial matters (Badrudin et al., 2021; Atika et al., 2021). Principals as managers must be ready to collect schools, the ability and willingness to emerge when school leaders can open up (Silviani et al., 2021; Mahmud \& Sanusi, 2021).

When it comes to carrying out their managerial responsibilities, principals must have the right strategy to empower their resources through collaboration, provide opportunities for them to advance their careers, and encourage the participation of all school members to achieve the shared goals that have been established (Bali et al., 2020; Pusvitasari, 2021).

The principal, as an administrator, is the principal who is responsible for the smooth running of all work and administrative activities in his school (Aryani et al., 2021). Sunarto (2011) explained that the principal as a category of education administration needs to complete the insight of educational leadership with anticipatory knowledge and attitudes towards changes that occur in people's lives, including education policies. As an administrator, the principal must have the ability to improve and develop all school facilities. Specifically, the principal is also required to manage the curriculum, address the administration of facilities and infrastructure, handle the administration of archives, and manage financial administration (Purwanti, AR, \& Yusrizal, 2014)

Observing activities and identifying which things are correct, which are not true, and not true allows the principal to be a supervisor, which is an activity that allows the principal to be suitable for providing guidance. When it comes to establishing a harmonious relationship with the environment, seeking out new ideas, integrating every activity, setting an example for all education personnel in schools, and developing innovative learning models, the principal as an innovator is the principal's strategy in establishing a harmonious relationship with the environment, seeking out new ideas, integrating every activity, setting an example for all education personnel in schools, and developing innovative learning models (Rahman \& Subiyantoro, 2021). According to Ancok (2012), the definition of innovation is a change from 
something, including both incremental and radical changes. The principal's role as an innovator will be reflected in the way he conducts himself in a constructive, creative, delegative, integrative, rational, and objective manner and his ability to be exemplary, disciplined, adaptable, and flexible in his work. (Nurmiyanti \& Candra, 2019; Salim \& Hasanah, 2021).

As a motivator, the principal must develop an effective strategy for motivating education staff to perform their various tasks and responsibilities. Because the principal believes that developing and improving work effectiveness and efficiency will develop and enhance work effectiveness and efficiency, his subordinates can be innovative to provide highquality education to students (Sabirin, 2012). The ability of principals to build motivation is one of the keys to improving the quality of good teaching (Kurniawan, 2020; Andriesgo et al., 2020). The ability of principals to build motivation is one of the keys to improving the quality of education because it collaborates with teacher performance (Fransiska, 2018; Kurniawan, 2020; Fauzi, 2021).

\section{CONCLUSION}

The involvement of women leaders in early childhood education can provide motivation and education to develop all the potential that exists in early childhood. Women who are known to be gentle, patient, and good at controlling themselves can set good examples and imitate their subordinates and students. The role of female leaders in realizing the potential of social intelligence in PAUD Aisyiyah runs optimally, as can be seen from students' attitudes that regularly begin to produce results by increasing their sense of independence, confidence, tolerance, speaking politely, and patiently. The polite culture program developed by the school principal can motivate students to develop their emotional-social intelligence, which can create a good attitude for their future.

\section{ACKNOWLEDGMENTS}

The researcher would like to express his gratitude to Kiai Haji Achmad Siddiq Jember, the Chancellor of the State Islamic University, for motivating the researchers and ensuring that this research was completed correctly. In addition, the researchers also thank the leaders, teachers, and employees of PAUD Aisyiyah Gilimanuk Jembrana Bali, who have helped in providing various needs needed during the research, either directly or indirectly.

\section{REFERENCES}

Aisyah, Amini, S. and, Mukti, Chandrawati, Titi, Novita, \& Dian. (2018). Perkembangan dan Konsep Dasar Pengembangan Anak Usia Dini. In Hakikat Anak Usia Dini. Universitas Terbuka, Jakarta.

Ancok, D. (2012). Psikologi Kepemimpinan dan Inovasi. In Jakarta: Erlangga.

Andriesgo, J., Riadi, H., \& K, J. H. (2020). Analisis Problematika Mutu Pendidikan Tingkat Dasar Berdasarkan Hasil Akreditasi Di Kabupaten Kuantan Singingi. Al-Tanzim: Jurnal Manajemen Pendidikan Islam, 4(2), 41-52. https://doi.org/10.33650/altanzim.v4i2.1099

Aryani, E., Hasanah, A. U., \& Putra, H. D. (2021). Effect of Head Management Competence on Teacher Performance in Sma Nusantara Plus. Al-Tanzim: Jurnal Manajemen Pendidikan Islam, 5(2), 105-114. https:// doi.org/10.33650/al-tanzim.v5i2.2177

Asmanah Rohmatun Sholehah, Saeful Anwar, H. (2016). Pola Kepemimpinan Perempuan dalam Pengelolaan Yayasan Lembaga Pendidikan. Tadbir: Jurnal Manajemen Dakwah, 1(1), 69-84. https://doi.org/10.15575/tadbir.v1i1.128

Astriani, S. A. (2019). Pendekatan Webbed Learning Pada Pembelajaran Tematik Terhadap Peserta Didik Inklusif Di Madrasah. Journal AL-MUDARRIS, 2(1), 79. https://doi.org/10.32478/al-mudarris.v2i1.220 
Atika, Arifin, Z., \& Jannana, N. S. (2021). Integrated School Management-Character Education Affirmation: A Case Study in Muhammadiyah Wirobrajan 3 Elementary. Al-Tanzim: Jurnal Manajemen Pendidikan Islam, 5(2), 15-26. https:// doi.org/10.33650/al-tanzim.v5i2.1970

Aulina, C. N. (2018). Penerapan Metode Whole Brain Teaching dalam Meningkatkan Motivasi Belajar Anak Usia Dini. Jurnal Obsesi : Jurnal Pendidikan Anak Usia Dini, 2(1), 1. https:// doi.org/10.31004/obsesi.v2i1.1

Badrudin, Gustini, N., \& Amirullah, C. I. (2021). Correlation of Financing Management Towards The Quality of Education in Madrasah Diniyah Takmiliyah Awaliyah in Bandung District. Al-Tanzim: Jurnal Manajemen Pendidikan Islam, 5(2), 96-104. https:// doi.org/10.33650/al-tanzim.v5i2.2163

Baharun, H. (2016). Manajemen Kinerja dalam Meningkatkan Competitive Advantage pada Lembaga Pendidikan Islam. Jurnal I Lmu Tarbiyah " At - Tajdid," 5(2), 243 262.

Baharun, H. (2017). Manajemen Mutu Pendidikan: Ikhtiar dalam Meningkatkan Mutu Pendidikan Madrasah melalui Pendekatan Balanced Scorecard. Tulungagung: Akademia Pustaka.

Bali, M. M. E. I., Muali, C., \& Munawaroh, L. (2020). Self-Efficacy sebagai Media Peningkatan Profesionalisme Guru di Madrasah. Risalah: Jurnal Pendidikan Dan Studi Islam, 6(1), 244-257. https://doi.org/10.31943/jurnal_risalah.v6i2.158

Br, R., \& Asiya, D. (2021). Inclusive Education Management in the Development of Cognitive Intelligence of Children. Al-Ishlah: Jurnal Pendidikan, 13(2), 1057-1067. https://doi.org/10.35445/alishlah.v13i2.538

Fachri, M., Wahid, A. H., \& Lailiyah, K. (2020). Joyful Learning Berbasis Hypercontent Dalam Meningkatkan Motivasi Belajar Siswa Pada Pembelajaran Pendidikan Agama Islam (PAI) di Sekolah. Edureligia: Jurnal Pendidikan Agama Islam, 4(2), 170-184.

https:// doi.org/10.24235/tarbawi.v4i1.4209

Fajri, Z., Muali, C., \& Farida, L. (2021). Student's Learning Motivation and Interest

Fajri, Z., Baharun, H., Muali, C., Shofiatun, Farida, L., \& Wahyuningtiyas, Y. (2021). The Effectiveness of Online Learning during COVID-19 Pandemic. Journal of Physics: Conference Series, 1899, 1-10. https://doi.org/10.1088/1742-6596/1899/1/012178 https:/ / doi.org/10.1088/1742-6596/1899/1/012178

Fardiah, F., Murwani, S., \& Dhieni, N. (2019). Meningkatkan Kemampuan Kognitif Anak Usia Dini melalui Pembelajaran Sains. Jurnal Obsesi: Jurnal Pendidikan Anak Usia Dini, 4(1), 133. https:// doi.org/10.31004/obsesi.v4i1.254

Fauzi, A., \& Muali, C. (2018). Menelusuri Jejak Dan Kiprah Kiai Mohammad Hasan Genggong; Dalam Membangun Kepemimpinan Spritual-Transformatif. Jurnal Islam Nusantara, 2(1), 17. https:// doi.org/10.33852/jurnalin.v2i1.56

Fauzi, I. (2021). Analysis of PTKIN Opportunities: Quality Measurement Through The Malcolm Baldrige Criteria for Using The World Class Universty. Al-Tanzim: Jurnal Manajemen Pendidikan Islam, 5(1), 1-13. https://doi.org/10.33650/altanzim.v5i1.1367

Fika, Y., Meilanie, S. M., \& Fridani, L. (2019). Peningkatan Kemampuan Bicara Anak melalui Bermain Peran Berbasis Budaya. Jurnal Obsesi : Jurnal Pendidikan Anak Usia Dini, 4(1), 50. https://doi.org/10.31004/obsesi.v4i1.229

Finori, F. D. (2019). Smart Techno Parenting: Alternatif Pendidikan Anak pada Era Tekhnologi Digital. Jurnal Tatsqif, 17(1), 52-69. https://doi.org/10.20414/jtq.v17i1.625 
Fransiska, R. (2018). Implementasi Total Quality Management Terhadap Budaya Kualitas. AL-ULUM: Jurnal Ilmu Sosial Dan Humaniora, 3(2). https:// doi.org/10.31602/alsh.v3i2.1197

Halilah. (2012). Kepemimpinan Wanita Dalam Manajemen Kependidikan. Jurnal: Manajemen of Education, 1(1), 1-9.

Hefniy, Bali, M. M. E. I., \& Asanah, K. (2020). Leader Member Exchange dalam Membangun Komunikasi Efektif di Pondok Pesantren. El-Buhuth: Borneo Journal of Islamic Studies, 3(1), 77-89.

Iltiqoiyah, L. (2020). Manajemen Pembelajaran melalui Pendekatan BCCT dalam Meningkatkan Multiple intelligences Anak. Jurnal Obsesi : Jurnal Pendidikan Anak Usia Dini, 5(2), 1368-1381. https:// doi.org/10.31004/obsesi.v5i2.781

Ilyasin, M., \& Zamroni, Z. (2017). Balanced Scorecard: A Strategy for the Quality Improvement of Islamic Higher Education. Dinamika Ilmu, 17(2), 223-236. https:/ / doi.org/10.21093/di.v17i2.703

Islaeli, I., Novitasari, A., \& Wulandari, S. (2020). Bermain Vegetable Eating Motivation (Vem) terhadap Perilaku Makan Sayuran pada Anak Prasekolah. Jurnal Obsesi : Jurnal Pendidikan Anak Usia Dini, 579-890. https://doi.org/10.31004/obsesi.v5i1.734

Kurniawan, A. (2020). Apakah Total Quality Management Meningkatkan Mutu Sekolah Menengah Atas Di Kota Cirebon? Al-Tanzim: Jurnal Manajemen Pendidikan Islam, 4(2), 79-90. https://doi.org/10.33650/al-tanzim.v4i2.1234

Mahmud, H., \& Sanusi, S. (2021). Training, Managerial Skills , And Principal Performance At Senior High Shool In North Luwu Regency. Al-Tanzim: Jurnal Manajemen Pendidikan Islam, 5(2), 27-39. https:/ / doi.org/10.33650/al-tanzim.v5i2.2150

Mahmud, M. E., Widat, F., \& Fuadi, A. (2021). Learning Management System in Streamlining Learning through Seamless Learning Approach. AL-ISHLAH: Jurnal Pendidikan, 13(2), 874-884. https:/ / doi.org/10.35445/alishlah.v13i2.787

Maysaroh, R. (2019). Upaya Guru Meningkatkan Kecerdasan Sosial Emosional Anak Melalui Bermain Peran di Taman Kanak-Kanak Nurul Huda Desa Suka Maju Kecamatan Mestong Kabupaten Muaro Jambi (Vol. 11).

Milles, M. B., \& Huberman. (2014). Qualitative Data Analysis: A Methods Sourcebook. USA: Sage Publications.

Minasari, A., Indraswati, D., Purwasito, A., \& Setiawan, I. A. (2021). Perkenalan Dunia Internasional sebagai Pendidikan Multikutural pada Anak Usia Dini melalui Metode Bermain Puzzle. Jurnal Obsesi : Jurnal Pendidikan Anak Usia Dini, 5(2), 2124-2133. https:// doi.org/10.31004/obsesi.v5i2.733

Munawar, M. (2019). Supervisi Akademik: Mengurai Problematika Profesionalisme Guru di Sekolah. Al-Tanzim: Jurnal Manajemen Pendidikan Islam, 3(1), 135-155. https://doi.org/10.33650/al-tanzim.v3i1.522

Nurhasanudin, \& Santika, T. (2021). Pendekatan Sentra Bermain Peran Untuk Meningkatkan Kecerdasan Sosial Emosional Anak Usia Dini. JoCE; Journal of Community Education, 2(1), 38-42.

Nurjannah. (2017). Mengembangkan Kecerdasan Sosial Emosional Anak Usia Dini Melalui Keteladanan. Hisbah: Jurnal Bimbingan Konseling Dan Dakwah Islam, 14(1), 50-61. https://doi.org/10.14421/hisbah.2017.141-05

Nurmiyanti, L., \& Candra, B. Y. (2019). Kepemimpinan Transformasional dalam Peningkatan Mutu Pendidikan Anak Usia Dini. Al-Tanzim: Jurnal Manajemen Pendidikan Islam, 3(2), 13-24. https:/ / doi.org/10.33650/al-tanzim.v3i2.646 
Nurvita, A., Alam, F., \& Abdullah, I. (2020). Kepemimpinan Kepala Sekolah Perempuan Dalam Meningkatkan Budaya Sekolah. Jurnal Administrasi Pendidikan UPI, 27(1), 42-52. https:// doi.org/10.17509/jap.v27i1.24399

Oktaria, R., \& Anggraeni, V. (2016). Social Emotional Intelligence At 4 - 6 Years Old At Early Childhood Institution In Bandung. CR Journal |, 2(2), 179-194. https:// doi.org/10.34147/crj.v2i02.37

Purwanti, K., AR, M., \& Yusrizal, Y. (2014). Kepemimpinan Kepala Sekolah Dalam Meningkatkan Kompetensi Guru Pada SMP Negeri 2 Simeulue Timur. Jurnal Ilmiah Didaktika, 14(2), 390-400. https:// doi.org/10.22373/jid.v14i2.510

Pusvitasari, R. (2021). Human Resource Management in Improving The Quality of Education. Al-Tanzim: Jurnal Manajemen Pendidikan Islam, 5(2), 125-135. https://doi.org/10.51276/edu.v2i2.132

Putri, P. I., \& Widiastuti, A. A. (2019). Meningkatkan Konsentrasi Anak Attention Deficit Hyperactivity Disorder (ADHD) dengan Pendekatan Reinforcement melalui Metode Bermain Bunchems. Jurnal Obsesi : Jurnal Pendidikan Anak Usia Dini, 3(1), 207. https:// doi.org/10.31004/obsesi.v3i1.177

Rahman, A., \& Subiyantoro, S. (2021). The Leardership Role of School Principals in Online Learning During the Covid-19 Pandemic. Al-Tanzim: Jurnal Manajemen Pendidikan Islam, 5(1), 165-175. https:// doi.org/10.33650/al-tanzim.v5i1.1805

Rahmatika, P., Hartati, S., \& Yetti, E. (2019). Metode Pembelajaran Mind Map dan Bercerita dengan Gaya Kognitif, Pengaruhnya terhadap Kemampuan Membaca Permulaan. Jurnal Obsesi : Jurnal Pendidikan Anak Usia Dini, 3(2), 548. https://doi.org/10.31004/obsesi.v3i2.260

Rusmawati, V. (2013). Peran Kepemimpinan Kepala Sekolah Dalam Upaya Meningkatkan Disiplin Kerja Guru Pada SDN 018 Balikpapan. E-Journal Administrasi Negara, 1(2), 395-409.

Sabirin. (2012). Perencanaan Kepala SekolahTentang Pembelajaran. Jurnal Tabularasa PPS UNIMED, 9(1), 111-128.

Salgado, F. S., de Oliveira, W. A., da Silva, J. L., Pereira, B. O., Silva, M. A. I., \& Lourenço, L. M. (2020). Bullying in school environment: The educators' understanding. Journal of Human Growth and Development, 30(1), 58-64. https://doi.org/10.7322/jhgd.v30.9969

Salim, S., \& Hasanah, E. (2021). Principal Leadership in Developing Al-Qur'an Learning Management. Al-Tanzim: Jurnal Manajemen Pendidikan Islam, 5(1), 83-94. https:// doi.org/10.33650/al-tanzim.v5i1.1673

Silviani, S., Maarif, M. A., \& Wibowo, A. (2021). Knowledge Sharing Management: Strategy for Improving the Quality of Human Resources. Al-Tanzim: Jurnal Manajemen Pendidikan Islam, 5(1), 129-139. https://doi.org/10.33650/altanzim.v5i1.1831

Sinaga, R., \& Doang, M. (2020). Mengembangkan Kecerdasan Interpersonal Anak melalui Metode Bermain. SIKIP: Jurnal Pendidikan Agama Kristen, 1(2), 104-114. https://doi.org/10.52220/sikip.v1i2.58

Sudrajat, C. J., Agustin, M., Kurniati, L., \& Karsa, D. (2020). Strategi Kepala TK dalam Meningkatkan Mutu Pendidikan pada Masa Pandemi Covid-19. Jurnal Obsesi : $\begin{array}{lll}\text { Jurnal Pendidikan Anak Usia Dini, 5(1), 508-520. } & \text {. }\end{array}$ https://doi.org/10.31004/obsesi.v5i1.582

Susanto, A. (2011). Perkembangan anak usia dini. In Jakarta: Kencana Prenada. Media Group.

Sutanto, E. M. (2000). Peranan Gaya Kepemimpinan Yang Efektif Dalam Upaya Meningkatkan Semangat Dan Kegairahan Kerja Karyawan Di Toserba Sinar Mas 
Sidoarjo. Jurnal Manajemen Dan Kewirausahaan, 2(2), 29-43. https:/ / doi.org/10.9744/jmk.2.2.pp.29-43

Umiarso, Rozi, F., \& Hidayati, N. (2022). Improving Children â€TM s Cognitive Intelligence Through Literacy Management. Jurnal Obsesi: Jurnal Pendidikan Anak Usia Dini, 6(3), 1588-1598. https:// doi.org/10.31004/obsesi.v6i3.1817

Wahid, A. H., Muali, C., \& Sholehah, B. (2018). Pendidikan Akhlak Perspektif Al-Ghazali. At-Tajdid: Jurnal Ilmu Tarbiyah, 7(2), 190-205.

Wibowo, A. (2021). Kepemimpinan Perempuan dalam Menciptakan Sekolah Ramah Anak. Quality, 9(1), 87-102. https:/ / doi.org/10.21043/quality.v9i1.10109

Yarmi, G., \& Wardhani, P. A. (2020). Efektivitas Pengembangan Karakter melalui Fun Garden of Literacy Bagi Anak Usia 7 Tahun. Jurnal Obsesi : Jurnal Pendidikan Anak Usia Dini, 4(2), 1068. https:/ / doi.org/10.31004/obsesi.v4i2.492

Yulianto, A. (2016). Pendidikan Ramah Anak: Studi Kasus SDIT Nur Hidayah Surakarta. At-Tarbawi: Jurnal Kajian Kependidikan Islam, 1(2), 137-156. https://doi.org/10.22515/attarbawi.v1i1.36

Zamroni, Amir, \& Saleha, L. (2021). Pengelolaan APE Berbahan Limbah untuk Meningkatkan Kecerdasan Kognitif Anak. Jurnal Obsesi: Jurnal Pendidikan Anak Usia Dini, 5(2), 1382-1395. https:// doi.org/10.31004/obsesi.v5i2.763

Zulkarnain, A. I., Supriadi, G., \& Saudah, S. (2020). Problematika Lembaga PAUD dalam Memenuhi Kebutuhan Tenaga Pendidik Sesuai Kualifikasi. Jurnal Obsesi : Jurnal Pendidikan Anak Usia Dini, 5(1), 14. https://doi.org/10.31004/obsesi.v5i1.491 